\title{
How an MBA contributes to the unfolding of careers: a comparative analysis
}

Book or Report Section

Accepted Version

Houldsworth, L., Brewster, C. and McBain, R. (2020) How an MBA contributes to the unfolding of careers: a comparative analysis. In: Premarajan, R. K., Forrier, A. and Arthur, M. B. (eds.) Career Dynamics in a Global World. Edward Elgar Publishing Ltd, Cheltenham, UK. ISBN 9781789901498 Available at http://centaur.reading.ac.uk/86517/

It is advisable to refer to the publisher's version if you intend to cite from the work. See Guidance on citing.

Publisher: Edward Elgar Publishing Ltd

All outputs in CentAUR are protected by Intellectual Property Rights law, including copyright law. Copyright and IPR is retained by the creators or other copyright holders. Terms and conditions for use of this material are defined in the End User Agreement. 


\section{www.reading.ac.uk/centaur}

\section{CentAUR}

Central Archive at the University of Reading

Reading's research outputs online 
<a> How an MBA contributes to the unfolding of careers: a comparative analysis

\section{$<$ b $>$ Introduction}

MBAs are viewed by many as a licence to practice as a manager regardless of context. But is an MBA 'universal' or do regional differences still prevail? Using a survey of over seven hundred alumni from a prestigious UK programme, we test the power of MBAs in globalising career outcomes and find that regional characteristics still endure.

Historically, the purpose of the MBA degree was to train (or re-train) individuals who were technically skilled to provide them with the functional knowledge and skills necessary to manage people and operations (Rubin and Dierdorff, 2013). From its origins in the USA, the MBA concept has grown into a single, globally recognised brand name in management education (Juusola et al., 2015; Mellahi, 2000), and some argue that it has become a prerequisite for senior posts (Baruch and Peiperl, 2000). If this universalistic approach to management is accepted, and universal prescriptions around how to manage apply in all contexts, then the 'best practice/one best way' taught on most MBA courses is appropriate. However, MBAs have been criticized for not reflecting the complexity, and socially and ecologically fraught nature of the world (Waddock and Lozano, 2013). 'Good' practice in one situation may not work in another. Using data from a UK MBA programme and theories of comparative capitalisms (Amable, 2003; Jackson and Deeg, 2008) we examine whether reported career choices, outcomes, and satisfaction post-MBA are differentiated by regional location. We conclude that context matters (Egri, 2013) and successful and legitimate management processes, and management careers, are likely to vary with type of market economy. 


\section{$<\mathrm{C}>$ Is the MBA a Homogenising Force?}

MBAs are popular: more programmes reported growing application volumes for the 20162017 class year than reported declining volumes (GMAC, 2016). Thus, the MBA continues to be a professional qualification associated with prestige, reputation, personal authority, and distinction (Doherty and Dickmann, 2009; Mayrhofer et al., 2004). Most applicants hope for increased job opportunities and increased salary potential (GMAC, 2016) and that does seem to be the effect (Zhao et al., 2006), irrespective of gender, MBA grade-point average, preMBA work experience, or ethnic background (Zhao et al., 2006). Completing an MBA requires a considerable investment and companies may fund this education, either partially or in full, as a means of investing in their human resources. Alternatively, individuals may selffinance, which may be interpreted as an example of 'individuals taking ownership of their own career' (Arthur et al., 2017; Crowley-Henry, 2006), or 'boundaryless careers' (Arthur and Rousseau, 1996; Guan et al., 2019).

There are alternative approaches to whether the MBA is a 'globalising' force. First, it is argued that the MBA is an example of the development of 'global mindsets' (Mellahi et al., 2013) by which home and host country identities are superseded. Acquisition of such academic credentials can facilitate greater transnational mobility for individuals (Waters, 2007). According to this approach, we might expect MBA alumni to have similar career experiences and behave in similar ways post-qualification. An alternative standpoint is presented by the growing literature on comparative human resource management (Brewster and Mayrhofer, 2012), which by its nature is more pluralistic. The comparative human resource management literature uses cultural and institutional theories to emphasize the differences between nation states and types of market. The comparative capitalisms literature (Amable 2003; Jackson and Deeg, 2008; Hall and Soskice, 2001; Whitley, 1999), on which much of this approach is based, 
implies that the management process, what would be seen as good management, and managerial careers, will vary from context to context, reflecting the territorial embeddedness described by Hall and Appleyard (2009).

The outcomes of management training and development may therefore differ depending on location and context, and this is likely to have a knock-on effect on the expectations of career development among the managers themselves. Ramirez and Mabey (2005) and Mabey and Ramirez (2011) have highlighted nationally distinctive approaches to management development, reflecting markedly different conceptions of what management means. As part of this argument, and given the dominance of Western, and particularly US, schools, the MBA credential has been criticized as 'ethnocentric' and 'neo-colonial' (Mellahi, 2000; Usdiken et al., 2004). These arguments are particularly relevant to our study, which revolves around a UK-based MBA programme being delivered (via blended learning) in a number of locations, including some 'developing states' (Nkomo, 2015).

Career success has been defined as 'the real or perceived achievement individuals have accumulated as a result of their work experiences' (Judge et al., 1999: 622) and has been divided into objective and subjective success ( $\mathrm{Ng}$ et al., 2005). Objective career success includes elements visible to everyone, such as promotions, and job moves. Subjective career success relates to the individual's own judgments about job attainment and satisfaction (Judge et al., 1999). Both may be impacted by perceived organisational support (POS), including funding. For this study we were also interested in former students' attribution for their career success: who /what did they think was responsible for it? Thus, there are parallels between this chapter and the one which is paired with it in this volume by Nair and Chatterjee. In the current study our focus, too, is on subjective career satisfaction. Both papers also note the role of agency in shaping career outcomes. 
<b> Different Types of Economy and Their Impact on Management Education and Development

We defined regional location according to the comparative capitalisms literature and used the three established groupings of coordinated market economies (CMEs), social democratic market economies (SDEs), and liberal market economies (LMEs), confirmed as relevant to personal development by Goergen et al., (2012) For countries included in each category see Table X.1. From the comparative capitalisms literature, we know that LMEs are based on competition between and within firms, and on a focus on short-term results for the owners of businesses. In the CMEs, firms collaborate much more with each other and with government, and are focused on survival and the long-term interests of a wider group of stakeholders. Firms are more supported, or restricted, by legislation. The Nordic SDE countries have fewer legal restrictions than CMEs but a more normative acceptance of a stakeholder approach to business, high trade union membership, high taxes, and high welfare provision (Amable, 2003). In terms of management education, one effect is that in the CMEs, employees tend to stay with one employer for longer, and transfers between firms are less common: so, for both employer and employee, investing in education and development becomes a more cost-effective decision in CMEs than in LMEs (Goergen, et al., 2012). We might expect that within CMEs, qualifications are highly valued; being sent on an MBA programme is a mark of selection as a high-potential and graduates are expected by their employer and themselves to remain in the organisation. As a corollary, we might expect CME graduates to be rewarded with promotions. In the LMEs, graduates may find their qualifications are given less credit and that they must change employer to make progress in their careers. Having changed employer, there may then be a wait before getting promoted. SDE graduates may be in a similar position to those from the CMEs. 
Given the diversity of our sample we were able to compare these established varieties of capitalism with two other regional groupings: Southern Africa and the Caribbean (see Table $\mathrm{X} .1)$

Table X.1 Country groupings used in this study

\begin{tabular}{ll}
\hline Type of Capitalism & $\begin{array}{l}\text { Number of } \\
\text { Respondents }\end{array}$ \\
\hline $\begin{array}{l}\text { Coordinated market economy countries - Belgium, France, Germany, and the } \\
\text { Netherlands }\end{array}$ & 88 \\
Social democratic economy countries- Denmark, Finland, Norway, and Sweden & 117 \\
Liberal market economy countries - UK, Ireland, Australia, and New Zealand & 411 \\
$\begin{array}{l}\text { Southern African countries -Botswana, Lesotho, Malawi, Mozambique, South Africa, } \\
\text { Tanzania, and Zimbabwe }\end{array}$ & 50 \\
Caribbean countries - Barbados, Guyana, St Lucia, and Trinidad and Tobago & 36 \\
\hline
\end{tabular}

There is little evidence in the literature about the kinds of market economy in the Southern African and Caribbean regions, though the Southern African model has been dubbed a segmented business system (Bischoff and Wood, 2012; Wood and Frynas, 2006), with employee-employer interdependence in large organizations and subsidiaries of multinational corporations (MNCs) but clear employee subordination in the extensive, informal, small firms. It is likely that all MBA students will come from large firms and the MNC subsidiaries sector, so that interdependence will be high. There is no literature to guide us as to the situation in the Caribbean.

\section{$<$ b> Do MBA Career Outcomes Vary by Context?}

What about career outcomes? Objective success might be measured by post-MBA career mobility in terms of number of promotions and changes to level of work. Contextual factors may be likely to influence the extent to which an individual will pursue advancement within their current organisation or by moving to another. From Whitley’s (1999) interdependence 
theory, we expect that it is more normal for individuals from a LME context to move between organizations in pursuit of career advancement, thus, to use the MBA for personal marketability. Randlesome (2000) suggests that in Germany employees enjoy career development and career enhancement without needing to move organisation whilst noting that despite German companies' preference for technical qualifications the addition of an MBA is likely to increase an applicant's prospects (Randlesome, 2000).

Other researchers have argued that the Nordic countries constitute a separate SDE group (Amable, 2003) with fewer legal restrictions than CMEs but a more normative acceptance of a stakeholder approach to business, high trade union membership, high taxes, and high welfare provision. La Porta et al. (1999) also note the distinctiveness of Nordic countries as something of a 'hybrid', typically displaying weaker vocational education and training than would be expected in a CME, and different labour market norms. These norms have been labelled 'flexicurity': focused on lifetime employment possibilities rather than the same employer (Goergen et al., 2012; Origo and Pagani, 2009),). In the light of these labour market norms, we might expect to see a higher level of training investment in SMEs than in CMEs.

Broadly similar arguments might apply to subjective career success (how the individual perceives their career situation). Randlesome (2000) described Germany, the leading CME, as an economy in which the MBA was gaining increased credence, with much of this pressure coming from potential applicants. Securing company support for such endeavours is likely therefore to be highly valued by the recipient. Qualifications in CMEs and SDEs tend to be given more value (House et al., 2004), so the kind of employees who undertake an MBA are likely to be in a close and continuing relationship with their employer. As Goergen et al. (2012) point out graduates in the CMEs and SDEs will have high job security meaning that there are fewer pressures for them to job hop or constantly to monitor the external labour market. This 
may translate into further promotions and a feeling of satisfaction with their investment in the MBA if promotions are perceived by the individual as a desired career outcome. Graduates in the LMEs will be in a less certain position, perhaps feeling that they may have to change employer to get ahead, and they may question the value of their qualification. Louw et al. (2001) report from a study in South Africa that no support could be found for the assertion that the MBA was a waste of time and money and that the value of the MBA qualification was overemphasized, whereas for the Caribbean it is difficult to assess beforehand what the situation will be

In the CMEs and SDEs, investments in development and, in particular, management development can take place over an extended time period, since the employer has more certainty that the employee will stay with the organisation after completing such programmes, and they are therefore more likely to get a return on their investment. Higher levels of training investment in SDEs than in CMEs (Goergen et al., 2012) might translate into higher perceived POS. Although there are no prior studies, we might expect something similar from the graduates in Southern Africa and the Caribbean, but for a different reason. This is because they are operating in a smaller employment market with the MBA having a high premium. Such graduates will not want to go into the small firm and/or informal sectors of the economy, and employment in the public sector, large firms, and MNC subsidiaries is limited. Employers will want to show faith in such employees in order to retain valuable staff. In the LMEs, firms are not heavily involved in skill formation and workers have an incentive to acquire general skills that are broadly portable across the various industries and firms in which they might seek employment (Thelen, 2007). In consequence, employers try to limit their investment, knowing that many employees will be moving (probably to a competitor, since they tend to stay in the same industry) within a few years, in order to secure their career progression. 
A final issue we examined in our research was who it is that graduates see as responsible for their career success. Ozbilgin et al. (2005) studied MBA students in Britain, Israel, and Turkey. The results were similar across these countries with the individual being responsible for their own success. We anticipate similar responses across the three established market economies of CMEs, SDEs, and LMEs, but that this may be different for the alumni from the Caribbean and Southern Africa, given that the MBA market is newer, and recipients may therefore feel like members of an elite group. Given that the cultures in the latter two regional groups are likely to be more hierarchical, and perhaps more religious, we anticipate that there may be less of a belief in the individual as the driver of career success with more recognition of the role of others (such as sponsoring employer or even Business School).

\section{$<$ b $>$ Methods}

We conducted an online survey of the MBA alumni of a leading international business school headquartered in the UK, whose students have an average age of 37, and around 10 years' managerial experience. We received 816 responses and we grouped the corresponding countries where respondents were based (not necessarily nationality) into regions, removing groups with less than 10 members. This resulted in a total of five groups and 702 respondents with year of graduation ranging from 1999-2013 as more recent graduates were not surveyed. Since the group composed of alumni from LME countries was considerably larger than the others, we selected a random sample of 110 members from this group and compared the results of the full sample with those using this sub-sample, in order to check that the results of the full data set were consistent. They were, and we use the results from the full sample, only reporting statistically significant results. 


\section{<c> Measures}

MBA alumni were asked to indicate job changes, employer changes and country changes since completion of the MBA. For objective career outcomes, MBA alumni were asked about the number of promotions they had received post-MBA, and their hierarchical level. For subjective career satisfaction we used a seven-item Likert scale to measure career satisfaction (based on an earlier study by Jokinen et al., 2008). We found the coefficient alphas to be 0.92 for satisfaction related to extrinsic factors and 0.77 for intrinsic factors.

For perceived organizational support respondents were asked to report their perception both pre- and post-MBA. Since these were measured at the same time, we recognize that there may be the possibility of self-report and retrospective memory bias. These measures were previously used by Jokinen et al. (2008). The reliability of the scale for pre- and post-MBA POS in this study was 0.89 . For attribution for career success, we asked respondents to reflect on their career development since their MBA and suggest whether any success they had enjoyed had been mostly due to themselves or others, and to identify the other if this was cited.

We included measures of respondent age, years since graduation, and gender (a dummy variable with female $=0$ and male $=1$ ) as control variables and no specific hypotheses were developed concerning their effects. We created grouping variables comprising three broadly equal sized groups from the numeric variables of age and years since graduation for the chisquare analysis in connection with objective career success.

\section{$<$ B $>$ Findings}

Alumni working in CMEs are least likely to remain in the same job post-MBA (9.1 per cent), followed by those from SDEs (12.8 per cent) and LMEs (14.0 per cent), while graduates from the Caribbean (22.0 per cent) and Southern Africa (18.0 per cent) are the most likely to remain 
in the same job. However, in terms of employer, as expected, CMEs report the highest frequency (36.4 per cent) of remaining, with the LME alumni reporting a lower likelihood (32.1 per cent). Alumni from SDEs are least likely (28.8 per cent) to have remained with their employer post-MBA. Alumni from CMEs are most likely to have changed country (33.0 per cent), followed by alumni from Southern Africa (22.0 per cent) and LMEs (19.5 per cent). These findings varied, as might be expected, with age and years since graduation. Multinomial logistic regression analyses indicate that region is not a statistically significant predictor, when controlling for age, years since graduation, and gender.

In terms of objective career success, we examined promotions and hierarchical position using chi-square for the variables level of work and region, while controlling for age and years since graduation (both of which were divided into three broadly equal groups), and gender. We find a significant association for senior management roles both pre- and post-MBA. Although CME alumni enjoy the greatest levels of objective career success post-MBA, with the highest average number of promotions and greater propensity to change job role and country, it is LME alumni who report the largest average increase in hierarchical position pre- and post-MBA.

Pre-MBA there is a significant difference in the reported hierarchical position, with students commencing the MBA from CMEs being less likely to report being in a senior management position than students from LME and SDE regions. Post-MBA, despite the considerable seniority gains achieved by CME graduates, it is alumni from LMEs and Southern Africa who are more likely to report being in senior management roles compared with those from CMEs, the SDEs and the Caribbean. It seems that the likelihood of being in a senior role is highest amongst LME alumni.

In terms of the subjective career, we expected satisfaction with career outcomes postMBA to be highest in the CMEs and lowest in the LMEs. Controlling for age, years since graduation, and gender, we found region was non-significant in terms of predicting satisfaction 
with objective career factors (salary and progress), though those from LMEs were least satisfied. Although region was not statistically significant, alumni from SDEs and CMEs were more satisfied in terms of subjective career success than those from LMEs. Of the control variables, only years since graduation was a significant predictor. Region did emerge as a significant predictor of pre-MBA POS and is also significantly related to post-MBA POS. Alumni from SDEs have significantly higher levels of post-MBA POS than those from CMEs, although they have significantly lower levels than alumni from Southern Africa, who reported highest POS. The lowest levels of post-MBA POS were reported by graduates from CMEs and the Caribbean. So, region does emerge as a significant predictor of POS post-MBA, but, surprisingly, alumni from CMEs report less POS than those from other regions and reported being less likely to have been fully funded than those from SDEs and LMEs. This may be because the MBA is seen as a way of easing movement between employers and in contexts where that is not the norm employers may be less enthusiastic. The higher POS within the SDE group may be because training is more highly valued there, so they are more likely to have received full funding for their studies than CME students. Indeed, around fifty per cent of alumni from both SDE and Southern Africa regions report full funding for their MBA studies.

Finally, we considered attribution for success across the five regional groups. Controlling for age, years since graduation, and gender, respondents from CMEs, SDEs, LMEs and Southern Africa all report similarly high levels of belief in their individual agency as the foundation of their career success thus echoing the findings of the Nair and Chatterjee paper (Chapter X). However, in the Caribbean region there is a greater tendency to attribute personal success to another in the form of the employer, the business school, or God.

\section{$<\mathrm{B}>$ Discussion}


A key theme emerging from this study is the limits of homogenisation with differences being reported in terms of MBA career trajectories by region. Whitley (1999) previously described CME employees as being more closely connected to their employer and less likely to change employer than those in LMEs and our study suggests that this also holds true for MBA graduates. Thus, despite the global recognition of the MBA qualification it does not overcome local labour market conditions emerging from variation in form of capitalism. This is reflected in the fact that one of the differences emerging from this study is the fact that LME alumni report the greatest frequency of changing country and transitioning from technical roles to senior management positions, this reflecting Whitley (1999). Interestingly, despite it being more 'normal' for MBA graduates from LMEs to move employers in pursuit of career gain, this mobility does not necessarily translate into career satisfaction, with LMEs appearing the least satisfied of all the groups.

If we turn our attention to the most satisfied students, these were from the SDEs and Southern Africa. In the case of the SDEs we expected to see greater investment in training and development (Goergen et al. 2012; Origo and Pagani, 2009,). Although less has been previously written about the emerging cadre of MBA graduates in Southern Africa our findings do resonate with the earlier research by Louw et al (2001).

Region also emerged as a significant predictor in terms of POS with alumni from SDEs reporting higher levels of post-MBA POS than is reported in LMEs, but not significantly so, and at a lower level than that perceived by alumni from Southern Africa. Alumni from CMEs felt they had the lowest support across all five regions post-MBA. Thus, it would appear that despite career stability, CME alumni may not feel supported in a market where external hiring is less common (Hamori and Kakarika, 2009). Once again, the emerging economies perform well with Southern Africa reporting the highest levels of POS reflecting the career benefits that learners attribute to their MBA qualification. 
In terms of possible future work, it would appear that satisfaction for MBA graduates is supported by employment security and perceived organizational support (including financial support for their studies). This is highlighted by the fact that the most satisfied grouping of Southern Africa and SDE also have the highest incidence of full funding (around 50 percent). Recent developments in the UK to provide an apprenticeship levy supported MBA process may provide an opportunity to explore this link more fully.

\section{$<\mathrm{B}>$ Conclusion}

The findings from this study support the application of the comparative capitalisms literature to career development. As anticipated, alumni from CMEs, despite having an MBA, do not mimic the behaviours of alumni from LMEs: they remain less likely to move employer. To a lesser degree the same is true of alumni in the less established economies of Southern Africa and the Caribbean, where there may be fewer opportunities. Given that in our study the respondents had all studied the same MBA programme, delivered via a UK based institution using common materials and teaching methods, we can suppose that differences must relate to the environmental context of work and careers. This is a key finding from this study, as it reinforces the notion that despite the much-heralded move towards globalisation, context matters and that this is reflected in management education and development. Thus, despite the global currency of the MBA as a qualification, the characteristics of local labour markets, as described in the comparative capitalism literature, endure. We do find some evidence for homogeneity. This is manifested in the mind set of MBA graduates around their personal attribution for career success as, with the exception of the alumni from the Caribbean, views were relatively uniform, reflecting what Ozbilgin et al. (2005) describe as a belief in individual agency in terms of career choice. 
In summary we conclude that, despite the claim that globalisation is creating homogeneity, a comparative analysis of MBA careers provides useful insights into the importance of context in management education. Thus, an understanding of labour market norms is helpful for ongoing analysis of the career outcomes of MBA level education. 


\section{REFERENCES}

Amable, B. (2003), The diversity of modern capitalism, Oxford: Oxford University Press.

Arthur, M. B., \& D.M. Rousseau (1996), The boundaryless career, New York: Oxford University Press.

Arthur, M.B Khapova, S.N, Richardson, (2017), An Intelligent career: Taking Ownership of your own career, Oxford: Oxford University Press

Baruch, Y. \& M. Peiperl, M. (2000), 'The impact of an MBA on graduate careers,' Human Resource Management Journal, 10 (2), 69-90.

Bischoff, C \& G.T Wood (2012), 'The practice of HRM in Africa in comparative perspective', In C. Brewster \& M. Mayrhofer (Eds.), Handbook of research on comparative human resource management, Cheltenham: Edward Elgar, 21, 494-511.

Brewster, C, \& M. Mayrhofer (Eds.) (2012), Handbook of research on comparative human resource management, Cheltenham: Edward Elgar

Crowley-Henry, M. (2006), 'The protean career' International Studies of Management \& Organisation, 37 (3), 44-64.

Doherty, N \& M. Dickmann (2009), 'Exposing the symbolic capital of international assignments' International Journal of Human Resource Management, 20 (2), 301-320.

Egri, C. (2013), 'From the editors: Context matters in management education scholarship' Academy of Management Learning and Education, 12 (2), 155-157.

GMAC (2016), 2016 Application trends survey report, Reston, VA: Graduate Management Admission Council.

Goergen, M.C.rewster,B. Wood, B. \& G. Wilkinson (2012) 'Varieties of capitalism and investments in human capital' Industrial Relations, 51 (1), 501-527.

Guan, Y, M.B Arthur, S.N. Khapova, R.J Hall \& R.G Lord (2019), 'Career boundarylessness and career success: A review, integration and guide to future research', Journal of Vocational Behavior 110 (Feb), 390-402

Hall, P. A \& D. Soskice (2001), Varieties of capitalism: The institutional foundations of comparative advantage, Oxford: Oxford University Press.

Hall, S \& L. Appleyard (2009) City of London, 'City of Learning? Placing business education within the geographies of finance' Journal of Economic Geography 9 (5), 597-617

Hamori, M.\& M. Kakarika (2009), 'External labor market strategy and career success: CEO careers in Europe and the United States' Human Resource Management, 48 (3), 355-378.

House, R.J, P.J, Hanges, M. Javidan, P.W Dorfman\& V. Gupta, (Eds.) (2004), Culture, leadership and organisations: The GLOBE study of 62 societies, London: Sage.

Jackson, G \& R. Deeg, R (2008), 'Comparing capitalisms: Understanding institutional diversity and its implications for international business' Journal of International Business Studies, 39, 540-561.

Jokinen, T, C, C. Brewster, \& V. Suutari(2008), 'Career capital during international work experiences: Contrasting self-initiated expatriate experiences and assigned expatriation' The International Journal of Human Resource Management, 19 (6), 979-998.

Judge, T. A, C.A. Higgins, C. JThoresen, \& M.R. Barrick (1999) 'The big five personality traits, general mental ability, career success across the life span', Personnel Psychology, 52, 621-652.

Juusola, K, K.Kettunen \& K. Alajoutsijarvi, K. (2015), 'Accelerating the Americanization of management education: Five responses from business schools', Journal of Management Inquiry, 24 (4), 347-389.

La Porta, R, F.Lopez-de-Silanes, A Shleifer \& R. Vishny (1999), 'Corporate ownership around the world', Journal of Finance, 54 (2), 471-517. 
Louw, L, J. Bosch D, Venter. (2001), 'Graduates' perceptions of the quality of MBA programmes', Quality Assurance in Education, 9 (1), 40-44.

Mabey, C., \& M, Ramirez (2011), 'Comparing national approaches to management development' in C. Brewster \& W. Mayrhofer (Eds.), Handbook of Research on Comparative HRM, pp. 185-210. Cheltenham: Edward Elgar.

Mayrhofer, W, A, Iellatchitch, M. Meyer, M. Steyrer, J. Schiffinger \& G. Strunk. (2004), 'Going beyond the individual: Some potential contributions from the career field and habitus perspective for global career research and practice', The Journal of Management Development, 23 (9), 870-884.

Mellahi, K. (2000), 'The teaching of leadership on UK MBA programmes: A critical analysis from an international perspective', Journal of Management Development, 19 (4), 297-308.

Mellahi, K., D, Mehmet., D. G, Collings, E, Tatoglu \& M, Hughes (2013), 'Similarly different: A comparison of HRM practices in MNE subsidiaries and local firms in Turkey', International Journal of Human Resource Management, 24 (12), 2339-2368.

Ng, T. W.H, K.L, Eby, K.L, Sorensen \& D.C, Feldman. (2005), 'Predictors of objective and subjective career success: A meta-analysis', Personnel Psychology, 58, 367-408.

Nkomo, S. M. (2015), 'Challenges for management and business education in a 'developmental' state: The case of South Africa' Academy of Management Learning and Education, 14 (2), 242-258.

Origo, R \& L, Pagani (2009), 'Flexicurity and job satisfaction in Europe: The importance of perceived and actual job stability for well-being at work' Labour Economics 16, 547-555.

Ozbilgin, M., F., Kuska, \& N, Erdogmus. (2005), 'Explaining influences on career "choice": The case of MBA students in comparative perspective' International Journal of Human Resource Management, 16 (11), 2000-2028.

Ramirez, M. \& C., Mabey. (2005), 'A labour market perspective on management training and development in Europe' International Journal of Human Resource Management, 16 (3), 291-310.

Randlesome, C (2000), 'Development Changes in management culture and competencies: the German experience' Journal of Management 19 (7), 629-642

Ritzer, G. (2011), The McDonaldization of society (6th ed.). Thousand Oaks, CA: Pine Forge Press.

Rubin, R. S., \& E.C, Dierdorff. (2013), 'Building a better MBA: From a decade of critique toward a decennium of creation' Academy of Management Learning and Education, 12 (1), $125-141$.

Sturdy, A., \& Y. Gabriel. (2000), 'Missionaries, mercenaries or car salesmen? MBA teaching in Malaysia' Journal of Management Studies, 37 (7), 979-1002.

Thelen, K (2007), 'Contemporary challenges to the German vocational training system', Regulation \& Governance (2007) (1), 247-260.

Usdiken, B, A. Kieser \& P. Kjaer (2004), 'Academy, economy and polity: Betriebswirtschaftslehre in Germany, Denmark and Turkey before 1945' Business History, 46 (3),381-406.

Waddock, S. \& J.M. Lozano. (2013), 'Developing more holistic management education: Lessons learned from two programs' Academy of Management Learning and Education, 12 (2), 265-284.

Waters, J.L (2007), 'Roundabout routes and sanctuary schools: the role of situated education practices and habitus in the creation of transnational professionals' Global Networks, 7, 477-497.

Whitley, R. (1999), Divergent capitalisms: The social structuring and change of business systems. Oxford: Oxford University Press. 
Wood, G., \& G. Frynas. (2006), 'The institutional basis of economic failure: Anatomy of the segmented business system', Socio-Economic Review, 4 (2), 239-277.

Zhao, J. J., A.D. Truell, M.W. Alexander, \& I.B. Hill. (2006), 'Less success than meets the eye? The impact of Master of Business Administration Education on graduates' careers', Journal of Education for Business, 81 (5), 261-268. 